\title{
A CAUSAL COMPARATIVE STUDY OF EDUCATIONAL LEADERS SENSE OF SELF EFFICACY IN THE CONTEXT OF TEACHER EDUCATION
}

\author{
Muznah Faheem \\ Associate Processor, \\ Govt. College of Education, \\ Sind, Pakistan \\ Email: muznahiqbal@ hotmail.com
}

\section{Iffat Sultana}

Associate Professor,

Department of Education, Iqra University,

Sind, Pakistan

Email: iffatsultana4@gmail.com

\begin{abstract}
Leadership is the key element of all educational endeavors. Leaders are the implementer of educational plans and innovations. Other educational departments are for their assistance. Effectiveness of leadership lies in leaders' sense of self-efficacy. The causal- comparative research study was conducted to elaborate the effect of gender on leadership skills with specific reference to self-efficacy. Simple Random sampling procedure is followed to select sample $(N=50)$ of educational leaders in the context of teacher education. Multiple data sources such as questionnaire, interviews, observations and informal discussions are used to collect the data. These modes of data collection make triangulation feasible. Hypotheses were tested statistically with the application of software (SPSS). The findings possess by the study are important and interesting such as in decision making educational leaders' sense of efficacy works as a driven force. There is no any significant difference in the sense of efficacy in both gender and both can be a successful leader. Majority of the female leaders enjoy instructional leadership style due to contextual realities, where females are under privilege, while male leaders are confident and reflective. But time management and objectivity of the task is difficult for them to manage. Recommendations are placed to modify the existing situation.
\end{abstract}

\section{KEYWORDS}

Educational Leaders, Sense of self efficacy, Gender, Teacher education 
INTRODUCTION

Building a sustainable future is a great challenge for all leaders. Many researches in points out that leaders' own belief and trust on their own abilities have a significant impact on their performance (Atasoy \& Cakiroglu,( 2018); Turnnidge \& Côté, (2018) \& Page, ; Pendergraft, \& Wilson, (2014)). The leaders' effective achievement is based on their belief that they are reaching the desired outcome. Effective leaders bring smart changes in the life of their followers. The effectiveness of leaders is depending on factors such as leaders socioeconomic background, formal schooling, preparation, training and cognitive ability (Elmore, 2000). Efficacy is a capability to reach desired outcome. In various domains of human functioning efficacy proved to be a useful motivational force. The goal oriented, resilient and motivated people are defined as efficious (Bandura, 1997).

The effective leaders are critical reflectors and collaborators (Fullan, 2005). They are capable to work in stressing condition. Due to contextual realities and nature of work. The leadership concept are quite different from the concepts of leadership in business. (Middlehurst, 2004). Role of educational leader is to promote the institution with the evolving need of the society. The education has to face a great loss because of covid'19 pandemic. Under these circumstances redefining the role of educational leader is the demand of the time (Paglis \& Green, 2002). So leaders are defined as committed people, goal oriented and able to solve the problems in efficious, practical and quick way (Yukl, 2006). The purpose is to investigate the educational leaders' level of self efficacy with reference to their gender in the context of teacher education. The study is also serving the purpose to understand the inner culture of our institutions and mind sets of our educational leaders. It is also fruitful for developing the criteria of selection, placement and promotion of educational leaders.

\section{LITERATURE REVIEW}

In late 1970's Albert Bandura put forward the concept of self-efficacy. According to him, self-efficacy is the ability to react to the situation (Bandura, 1997). Social Cognitive Theory serves as the theoretical framework for this study because it is the theoretical foundation for leadership self-efficacy. An individual's behavior to participate in leadership is influenced by its self-efficacy. The sources of self-efficacy are mastery experience, vicarious experience, social persuasion and physiological factors (Bandura, 1993). In simple words ability to perform any task is depend on previous experience, training and environment.

Self-efficacy beliefs are task and context specific. Principals feel efficacious for leading in particular context (Tschannen-Moran \& Gareis, 2005). Leaders' strong sense of self efficacy let them to enjoy the challenging situation and sharpen analytical and reflecting skills (Stevenson, 2015). They have sense to enjoy the extreme position 
of swing. Their personality traits show dominancy of extrovert behavior. High level of participation and interest in different activities and quick recovery from setbacks and disappointments is the indication of high sense of efficacy (Stevenson, 2015). Due to an ability to mold the situation their sense of humor is high. For achieving targets people with strong efficacy do not get aggressive overly. Extreme aggression is a sign of low self-efficacy and lack of confidence. Teachers' weak sense of efficacy let them to avoid challenging task and prefer to stay in comfort zone. Due to weak communication and reflective skills, they are hesitant and always see dark side. Majority of them are introvert with weak sense of humor. Usually feel depression and stress problem (McCormick, 2001).

In brief it is said that educational leaders with high level of self-efficacy are skilled full in giving instructions, questioning, explaining, using audio visual aids and provide multiple options to their subordinates and followers even with lower order thinking. While the educational leaders with low efficacy adopted more custodial than humanistic approach. They feel difficulty in managing the faculty on task and in accommodating the followers with multiple abilities (Jacob \& Lefgren, 2008).

Swan, Wolf \& Cano (2011) in their study "Changes in teachers' self- efficacy from the student teaching experience through the third year of teaching" tried to understand the association between sense of self efficacy and experience of teaching. The conclusion derived indicates high level of efficacy at student teaching level, it is because of enthusiasm of adopting the profession (new entry) while low efficacy at first year of teaching. As the process of mentoring and supporting environment are missing. Gradually the sense of efficacy increases as they progress in the field. It shows adjustment and familiarity with staff environment and administrative officials. Same is in the case of educational leaders when they indulged in the profession they expresses high sense of efficacy but as they progress in the profession their efficacy level show continues decline and this is due to very less professional support. Recently in Karachi a bulk of schools headmasters and headmistress have been selected and indulged successfully in the profession. It's the first time in our educational history that leadership is directly recruited by Institute of Business Administration (IBA) Sukkur University after transparent selection and training in 2017 (The News International, Karachi. 2017 June $2^{\text {nd }}$ ). These young leaders were very ambitious and energetic but they face lots and lots of problems in the fields. These challenges were ranges from mere unavailability of funds to political affiliation of institutions or some of the staff members. Researches proved that an institution's pleasant atmosphere can boost up teachers' sense of efficacy (Hoy \& Woolfolk, 1993) and friendly attitude of administrator (Hipp \& Bredeson, 1995). So the environment conducive for learning is essential for boosting up the teachers sense of efficacy. This is only possible by efficacious leader. 
Jacob \& Lefgren, (2005) described that to provide good results at a larger scale the abilities required are vision, direction, motivational capacity, technology management skills, creativity, and innovation for working in the learning environment and adaptability for the changing context. The highly effective educational leaders identify, cultivate and nurture the faculty. Gender is important in determining the maximum level of potential and effectiveness achieve by a leader. Man and women both can be a effective leader. Usually it is observed that women are more transformational leaders and practice participatory leadership style while men posses authoritarian style of leadership. It is also said that leaders gender define its reaction to the situation many researchers relate masculinity with a task-oriented leadership style and femininity with a relationship oriented leadership style (Shanmugam et al., 2019). According to Eagly \& Johannesen-Schmidt (2003), men are more assertive, ambitious, aggressive, independent, self-confident, and competitive in the decision-making. Women are more affectionate, helpful, kind, sympathetic, sensitive, and gentle (Patel, 2013). In critical situations women react more emotionally than men, so when an immediate response is required, men react by action whereas a women get into tears (Gorska, 2016).

Furthermore it has been emphasized in the literature that clear sense of responsibility and intention are the essential feature of successful leadership (Levine, 2005). Some other roles of the educational leadership are estimating risk factor, support innovation and creativity, fair assessment of strengths and weaknesses, competition and confidence in the governance of the institution (Flinn \& Mowles, 2014). Siwatu, \& Chesnut, (2015) claims that self-efficacy matters a lot in the pre-service and in-service educational development career development. Their adjustment and promotion both based on their level of self-efficacy.

The leaders with high qualification but less sense of self efficacy finds it difficult to lead others. Leaders' sense of self efficacy badly depends upon their self-image and self-actualization (McCormick, 2001). Sense of self efficacy can be constructed by self-authority and self-authority is defined as courage to define you (Paglis \& Green, 2002). Collective self-efficacy and self-efficacy has some interdependency. The work place facilities and positive environment construct collective self-efficacy while persons' positive life experiences construct its self-efficacy (Bandura, 2000).

Thus it can be summarized as our responses and emotional reactions to the situation depends on our level of self-efficacy plays (Bandura, 1993). Our own belief about our capabilities in achieving the desired goals depends on personal circumstances, mood, emotional stability and level of stress. Situation, difficulty of task and internal mood shapes our self-efficacy. Self-efficacy beliefs are free of gender, educational level and socio economic status it solely depend on your personality traits. 


\section{RESEARCH QUESTIONS}

1. Does the sense of self efficacy in decision making vary according to gender?

2. Does efficacy to influence school resources of educational leaders depend on their gender?

3. Does Female leadership is keen in efficacy to community involvement?

\section{RESEARCH HYPOTHESES}

1. Sense of self efficacy in decision making vary according to gender

2. Gender play vital role in efficacy to influence school resources

3. Female educational leaders are keen in efficacy to community involvement

\section{RESEARCH METHODOLOGY}

This causal- comparative study is designed to find the association between the leaders' sense of efficacy and its' gender. Here quantitative and qualitative data are tested to find the solution of single problem. Cresswll and Tashakkori (2007) defines mixed method research as "a research in which the investigator collects and analyze data, integrates the findings and draws inferences using both quantitative and qualitative approaches". Gathering the data through multiple sources such as observation, interviews and informal discussions makes the triangulation possible. Percentage method and independent sample T-test were applied to test hypotheses statistically.

\section{Sample}

Sample is the small proportion of the population selected for analysis. Simple random sampling method is adopted for the selection of the educational leaders of teacher education institutions $(\mathrm{N}=150)$. Educational leaders up to third cadre (principals, vice principal, coordinators and subject heads) were the part of study. The number of the educational leaders included in the study is one hundred and fifty. These educational leaders are from all over Karachi including rural and urban areas.

\section{Instrumentation}

Following instruments are applied as a tool for data collection.

Likert scale questionnaire: Questionnaire on Likert scale is adapted for collecting the data related to educational leaders' sense of self efficacy. The sense of self- efficacy scale developed by Tschannen-Moran, \& Woolfolk Hoy, (2001) with Chronbach's alpha .90 has been adapted to study the problem. This questionnaire is based on these seven variables. All these seven variables are important as it discuss the different angles of educational leadership. The rationale of selecting only three variables such as efficacy in decision making, efficacy to influence in resource management and efficacy in parental involvement is that the role of leader shows variance according to their gender. Furthermore these are the areas where leaders have to play very crucial role. The first sections request the respondent's demographic information such as 
designation, place of posting, salary, gender, ethnicity and teaching methodology.

\section{Interview}

Interviews from responsible and dominating body of teacher education is conducted to understand the scenario and for achieving first and information of the research problem Interviews are conducted from authoritarians such as Principles of two teachers' training colleges, Group interviews are conducted from almost three female educational leaders (co-coordinators \& In-charges) and four male educational leaders (co-coordinators \& In-charges)

\section{Observation}

Unstructured observations are held for the triangulation of the data. Some of the basic observations are noted down such way of leading, leaders' interactions, overall environment of the institution, different dialects and emotions expressed by educational leader while performing the daily tasks etc.

\section{DATA ANALYSES}

SPSS (special package for data analyses software is applied to analyze the gathered data through five point Likert scale questionnaire and qualitative data is analyzed through thematic approach by coding and decoding the data. Pointing words and recognizing patterns in the data and patterns gathers to give sequence and interpretative strategy is applied to detect the themes. Verbatim transcription was maintained to enhance the credibility of the data. Triangulation mixed method research model is applied, in which both quantitative and qualitative data collect and processed together to increase the credibility of the research. Both type of data is treated equally and intensively to minimize the randomization. The hypothesis were tested statistically and analyzed scientifically.

Table of demographic data

The demographic attributes of the participants are presented in the table.

\begin{tabular}{ccccc}
\hline S.No. & Variables & Categories & No & \% \\
\hline 1. & Gender & Male & 60 & 40.00 \\
& & Female & 90 & 60.00 \\
& & Total & 150 & 100.00 \\
2. & Experience & 01 to 05 years & 28 & 18.60 \\
& & 06 to 10 years & 50 & 33.00 \\
& 11 to 15 years & 60 & 40.00 \\
& 16 to 20 years & 10 & 6.60 \\
& 21 and above & 02 & 1.30 \\
3. & Total & 150 & $100 \%$ \\
& Public & 80 & 53.30 \\
\hline
\end{tabular}




\begin{tabular}{cccc}
\hline Type of & Private & 70 & 46.60 \\
school & Total & 150 & $100 \%$ \\
\hline
\end{tabular}

About $60 \%$ participants were females representing the gender distribution of leaders in the population. Similarly $60 \%$ of the population has experience between eleven to fifteen years. $80 \%$ of the participants are from public sector teacher education institutions providing free education. In government institutions many of the principals got the post through promotions policy. Actually head majority of the heads were the senior most staff member and they are experienced teacher educators as well. They have length of teaching and assessing experiences instead of administrative matters.

\section{Hypothesis 1}

Sense of self efficacy in decision making vary according to gender

\section{Levine's Test \\ for Equality of \\ Variances}

t-test for Equality of Means

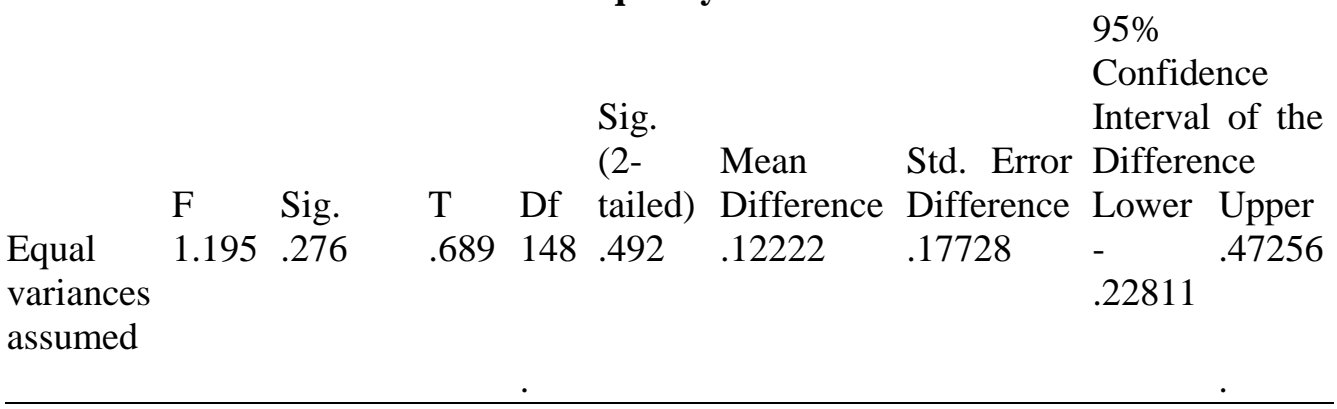

Independent sample T-Test was conducted to test the hypothesis as gender has no impact on sense of efficacy in decision making. According to decision rule the p-value is 0.276 which is greater than 0.05 the hypothesis is rejected. That means there is gender difference in the sense of efficacy for decision making I-e U1=U2

\section{Interpretation}

The t-test was conducted for the group of male (\#60) and female (\# 90) educational leaders up to third cadre (principals, vice principal, coordinators and subject heads). For males (mean $=4.000$ and $\mathrm{SD}=1.2)$ and for female $($ mean $=3.4$ and $\mathrm{SD}=.96)$ which is not significantly different. This shows the weak relationship among the sense of efficacy in decision making of the two independent group samples males and females. The value of significance is .276. The rejection of the null hypothesis shows that the sense of self efficacy in decision making is based on their gender. So the concept that there is in justice with females in Pakistan especially in the context of professional environment is not true in term of their decision making power. 


\section{Convergence}

Thematic analyses of the qualitative data reveal that decision making is a very difficult process and making right decision at right time needs multiple skills and observations."In same circumstances the decision of two professional are totally

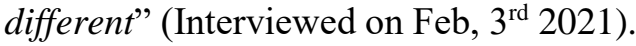

"Being a female I can't take challenging decision and I need to consider my limitations"(Interviewed on Jan, 10 $0^{\text {th }}$ 2021).Female educational leaders are quick in decision making but they have difficulty to sustain the decision ones taken. Male educational leaders are quite reluctant they take decision when there is some mishap or crisis. They didn't believe that decision making is a complex process and it reflects our future endeavor. "I thought we just wait GOD is there to take best decisions for us" (Interviewed on Jan 21 $1^{\text {st }}$ 2021). In academic environment leaders decisions should be based on vision and mission statement of the institution. One of the educational leader commented that "I take the decision based on possibilities or what is feasible in the present circumstances" (interviewed on Jan, $4^{\text {th }}$ 2021). According Kurt, Duyar \& Çalik, (2021), while taking different decisions principals have to switch off their role and have to change the cap quickly. Some time they have to play the role of facilitator and some time as a dictator in order to achieve the required outcome. The qualitative data reveals that females are more critical and logical in making decisions "I didn't make quick decisions....In my opinion decision making is a process not an attempt" (Principal teacher training college). In view of other participant, "Decision making is stressful; I usually believe in GOD, HE makes the decision for me.....(Interviewed by Principal teacher training college, 12 Feb, 2021)" Talking about the decision making process, "we all are friends in our college one of my favorite faculty member, he is very close to me, and usually make quick and wise decisions" (interviewed on $22 \mathrm{Feb}$, 2021). In experts opinion, "Decision making is a thinking process, it needs critical reflections, logical thinking and determination" (interviewed on $22^{\text {nd }} F e b, 2021$ Leadership and management student AKU-IED). Furthermore, "Most of our success and failure depends on our decisions, right decision on right time have positive impact on your achievements" (interviewed on 25 $\left.5^{\text {th }} \mathrm{Feb}, 2021\right)$. "Most of the household decisions are taken by mother(female) in matriarchy families, while patriarchy families father play dominant role and majority of the family member feel frustrated" (interviewed on $25^{\text {th }} \mathrm{Feb}, 2021$ )

\section{Hypothesis 2}

Gender play vital role in efficacy to influence school resources Independent Samples Test 
Levine's Test

for Equality t-test for Equality of Means

of Variances

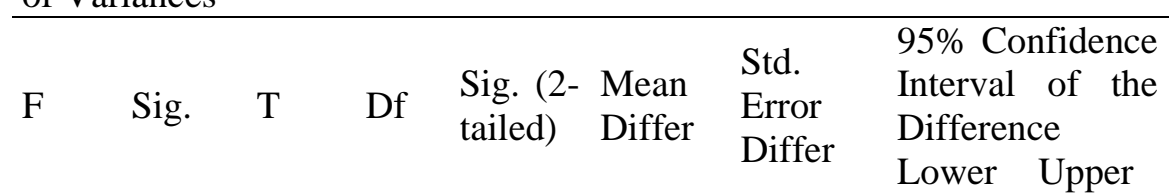

Equal

varianc

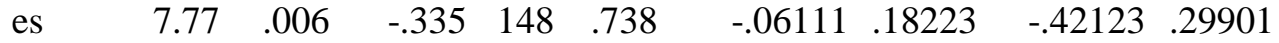

assume

d

According to decision rule the p-value is .006 which is less than 0.05 the hypothesis is accepted. That means there is no gender difference in the sense of efficacy in resource management (U1 is equal to $\mathrm{U} 2$ ).

\section{Interpretation}

The t-test was conducted for the group of male (\#60) and female (\# 90) educational leaders. For males (mean=3.8500 and SD $=1.176$ ) and for female (mean $=4.0111$ and $\mathrm{SD}=1.034)$ which is not significantly different this shows the strong relationship among the sense of self efficacy of group samples.

The value of significance is .006 . The acceptance of the null hypothesis shows that the sense of self efficacy in resource management is independent of their gender.

\section{Convergence:}

The qualitative data related to resource management points out that resource management is the basic task of leaders. They have to keep the balance between available resources and the task orientation. One of the interview participant said that "Some time it is quite challenging to manage the appropriate resources in appropriate period of time" (interviewed on Jan, 4th 2021). Some of the educational leader commented that "Arranging multimedia for workshops is huge task in limited budget" (Interviewed on Jan, 10 $0^{\text {th }}$ 2021). In respect of sense of efficacy in resources management it is said that, "In our education system and in teacher education colleges under the umbrella of government...resources like charts, markers, internet and other accessories are not possible" (Interviewed on Jan 21 $1^{\text {st }} 2021$ ). General observations of the education system reflect that it is due to limited budget.

\section{Hypothesis 3}

Female educational leaders are keen in efficacy to community involvement Independent Samples Test 


\section{Levene's Test for Equality of Variances}

\begin{tabular}{|c|c|c|c|c|c|c|c|c|}
\hline & $\mathrm{F}$ & Sig. & $\mathrm{T}$ & Df & $\begin{array}{l}\text { Sig. } \\
(2- \\
\text { tailed) }\end{array}$ & $\begin{array}{l}\text { Mean } \\
\text { Difference }\end{array}$ & $\begin{array}{l}\text { Std. Error } \\
\text { Difference }\end{array}$ & $\begin{array}{l}95 \% \\
\text { Confidence } \\
\text { Interval of the } \\
\text { Difference } \\
\text { Lower Upper }\end{array}$ \\
\hline $\begin{array}{l}\text { Equal } \\
\text { variance } \\
\text { assumed }\end{array}$ & .08 & .867 & - & 148 & .062 & -.23889 & .12697 & $\begin{array}{ll}-.4899 .0121\end{array}$ \\
\hline
\end{tabular}

According to decision rule the $\mathrm{p}$-value is .867 which is greater than 0.05 the hypothesis is rejected (U1is not equal to $\mathrm{U} 2$ ).

\section{Interpretation}

The t-test was conducted for the group of male (\#60) and female (\# 90) employee. For males (mean=3.7000 and $\mathrm{SD}=.77$ ) and for female (mean $=4.9389$ and $\mathrm{SD}=.74$ ) which is significantly different. This shows the weak relationship among the sense of self efficacy in community involvement.

The value of significance is .867 . The rejection of the null hypothesis shows that the sense of self efficacy in community involvement is free from its gender. So the concept that there is in justice with females in Pakistan especially in the context of professional environment is not true in term of their sense of self efficacy in community involvement.

\section{Convergence}

Community involvement is one of the major elements of educational leadership. "Schools are the mini societies so they must reflect our societal cultural and ethical views" (Interviewed on Jan, 4th 2021). SMC or school management committee headed by the parent of one of the student while principal of the institution would be the joint secretary and all parents are members of the association. In most of the institution where there is female leadership they maintain the proposed structure of SMC very successfully but male feel difficulty in attaining this desired objective. "Once upon a time we call the parents but their response was hopeless" (Interviewed on Jan, $10^{\text {th }}$ 2021). In response to the query about parental involvement in educational institutions one of the educational head commented that, "The heads, who are well dressed have good impact and show high level of efficacy in parental involvement" (Interviewed on Jan 21 2021). Furthermore, the most important is your intonation, ascent and welcoming attitude towards community "The heads should possess public speaking 
ability" (Interviewed on Feb, $3^{\text {rd }} 2021$ ). Lastly it can be concluded that, "Successful administration is impossible without community involvement" (Interviewed on Feb, $13^{\text {th }}$,2021). Majority of the researches on parental involvement suggested that parental involvement is crucial for inclusive and quality education.

\section{DISCUSSION}

The main purpose of the study was to explain educational leaders, level of self-efficacy with reference to their gender in context of teacher education. For this purpose selfefficacy scale Tschannen-Moran, \& Woolfolk Hoy, (2001) was adopted with the belief that general self-efficacy is a universal construct (Scholz; Dona,; Sud, and Schwarzer, (2002)). The descriptive statistical methods was applied to test the hypothesis. The results demonstrate that gender has impact on self-efficacy in decision making while self-efficacy in resource management and community involvement is free from gender effect.

It is universally accepted that positive psychology is required for leaders to lead effectively (Dumay \& Galand, 2012). This positive thinking is also required to handle tumultuous or hectic situation, although other traditional ways are equally important for effective leadership (Friedman, 2005). Many researches recommended that selfefficacy is more important for transformational leader because when innovations are intervene in the organization then self-efficacy or spirit is required to implement it (Dumay \& Galand, 2012). Therefore the self-efficacy becomes more important. The focus of the study is educational leadership which emphasizes on change as education is a change process which demands strong sense of efficacy. Low efficacy of leaders make the followers slow, lazy and weary, so for transformational leadership selfefficacy is a stronger factor (Schyns, 2004). On the other hand the educational leaders have to keep the balance between imposed policies and orders along with employee's needs (Fink, \& Resnick, 2001), under these circumstances self-efficacy of leaders do not have significant impact on effectiveness of leadership. Simultaneously the importance of self-efficacy for leaders cannot be neglected because it is needed to develop team work and to make the task done under the defined criteria (McCormick, 2001). Moderate level efficacy is needed to run government institution. Heads continuous feedback and appreciation maintain moderate level of efficacy in employees. It is obvious that self-efficacy has less to do with effectiveness but it is more important for optimizing the leader employee relationship (Mojavezi \&Tamiz, 2012).

Klassen and Chiu (2010) observed curvilinear relationship between teachers' sense of efficacy and their teaching experience. They identified that the teachers' sense of efficacy increased from zero year of experience to approximately twenty three years and then slowly and gradually start declining. On the other hand Vaudroz, Berger \& 
Girardet (2015) study, about the role of teaching experience and teachers' prior education in teachers' self-efficacy and general pedagogical knowledge in leadership emphasize the importance of individual characteristics such as experience and prior education in understanding heterogeneity. The general pedagogical knowledge and teachers sense of self efficacy are two important constructs that directly influence on teachers' and students' achievements' in the academic settings. The seven dimensions of the teachers' self- efficacy scale (Short form) developed by Tschannen-Moran, \& Woolfolk Hoy, (2001) successfully express the core elements of an quality leadership. These dimensions were efficacy in decision making, in school resources, in instructional, in disciplinary, in parental involvement, in community involvement and in creating positive school climate. All these seven variables are important as it discuss the different angles of educational leadership. According to the findings of the study gender difference regarding leadership experience and leadership effectiveness emerged in group where men showed high self-efficacy in some dimension as compared to women. It is believed that this finding is relevant, as it is consistent with the literature on gender stereotype. Simultaneously it is also co-relate to the Bandura self-efficacy theory (1997), which states that self-efficacy expectations are based on individual and vicarious experience. Limitations of the study include sample recruitment and procedure. Major composition of study reliance on questionnaire and focused group interviews only, though these limitations are popular in the field of research and education.

\section{FINDINGS}

In decision making sense of efficacy works as a driven force

On the other hand male and female educational leaders possesses same level of efficacy, but

Majority of female leaders are experiencing instructional leadership style due to our traditional setup, where females are under privileged class of the society.

Simultaneously the data analyses also revealed that majority of the males are reluctant in managing the task timely and objectively but confident and competent.

In Likert scale "Quite a bit" is explained by educational leaders in expressing their opinion on crucial college matters. It demonstrates laissez-faire style of leadership.

Side by side majority of the educational leaders have weak sense of efficacy in managing instructional material for classroom activities and SMC (School Management Committee) and teachers parents meeting is the only platform for community involvement in schools.

Educational leaders demonstrate weak sense of efficacy in involving businessman from the community.

They have weak sense of efficacy for developing coordination with other educational institution. So it can be concluded as leadership is not about one person's capabilities but it's about building a shared commitment and developing a strong team spirit 
Turnnidge, \& Côté, 2018).

\section{RECOMMANDATIONS}

Play different games and adopt strategies to improve decision making and sense of efficacy in young children at school level so that in future we will get leaders with firm determination.

Distributive leadership style should be followed by female leaders for enhancing accuracy of task with strong sense of efficacy.

Time management is one of the important attribute which leaders have to portray as high level of efficacy (Niyogi \& John, 2017), so provide meaningful training to the leader to develop this skill.

Define separate cadre for educational leaders like principals, vice principal, cocoordinators and subject specialist which will assist the leaders to demonstrate strong sense of self efficacy.

Many researchers suggest intensive internship for pre-service leaders.

Case study and problem solving should be the technique along with reflection for minimizing the theory practice gap.

Educational leaders should be appointed through direct selection board. For conceiving their role as a pedagogical leader, trainings are important for them with strong sense of efficacy.

Crises management should be the part of leadership training.

Educational leaders should be trained just like CSS (Central Superior Services) trained officers. Educational leaders should be capable to face the public gatherings confidently.

It is said that fixing what's' wrong with leadership training is essential but it is not enough (Levine, 2005). Their training should be based on building in them some qualities such as public speaking and to compact the ideas along with its successful implementation.

The study indicates positive association between educational leaders' sense of efficacy and their performance. The leaders with high level of efficacy take excellent academic decisions. Administrative management and financial management can best be performed by officious leaders only. Some of the ideas evolved from the study for future researches are: to correlate the teacher and students level of self-efficacy. Furthermore, to study the impact of different leader ship style on teachers' efficacy level and the correlation between provision of conducive learning environment and students' sense of efficacy.

\section{REFERENCES}

Andrews, R. N. L. (2012) History of environmental leadership. In: Gallagher, D. R. (Ed.) 
Environmental leadership: A reference handbook, Vol. 1. SAGE Publications, Los Angeles, pp. 17-28.

Bandura, A. (1993).Perceived self-efficacy in cognitive development and functioning. Educational Psychologist, 28, 117-148.

Bandura, A. (1997). Self-efficacy: The exercise of control. New York: W.H. Freeman and company

Bandura, A. (2000). Cultivate self-efficacy for personal and organizational effectiveness, In E.A. Locke (ed.) The Blackwell Handbook of Principles of organizational Behavior (pp.120-136). Malden, MA: Oxford University Press.

Best, J. W. (1977). Research in education. Englewood Cliffs, N.J: Prentice-Hall.

Creswell, John W. (2009) Research design: Qualitative, Quantitative and Mixed methods Approaches ( $3^{\text {rd }}$ edition) SAGE Publications

Creswell, J. W., \& Tashakkori, A. (2007). Developing Publishable Mixed Methods Manuscripts. Journal of Mixed Methods Research, 1, 107-111.

Dumay, X., \& Galand, B. (2012). The multilevel impact of transformational leadership on teacher commitment: cognitive and motivational pathways. British Educational Research Journal, 38(5), 703-729.

Eagly, A.H., Johannesen-Schmidt, M.C., \& Van Engen, M. L.(2003). Transformational, transactional, and laissez-faire leadership styles: A meta-analysis comparing women and men. Psychological Bulletin, 129(4), 569-591.

Elmore, R. (2000). Building A New Structure For School Leadership. Washington, D.C.: The Albert Shanker Institute.

Fink, E. \& Resnick, L.B. (2001). Developing Principals as Instructional Leaders. Phi Delta Kappan, 82 (8), 598-606.

Friedman. T. L. (2005). The World is Flat: The Globalized World in 21st Century. London Penguin Group.

Flinn, K. and Mowles, C. (2014). A Complexity approach to Leadership development: developing practical judgment. LFHE stimulus paper London: Leadership Foundation for Higher Education

Fullan, M. (2001). The New Meaning of Educational Change (3rd Ed.). Toronto: Irwin Publishing Ltd.

Gorska, A. (2016). Gender Differences in Leadership. Studia i Materiaïy, 1/2016(20), 136-144, Wydziaï ZarzÈdzania UW.

Hipp, K \& Bredeson, P. (1995). Exploring connections between teacher efficacy and principals' leadership behavior. Journal of School Leadership, 5 (2), 136-150.

Hoy, W. \& Woolfolk, A. (1993). Teachers' Sense Of Efficacy And The Organizational Health of Schools. The Elementary School Journal, 93,356-372.

Jacob, B. A., \& Lefgren L. (2008). Can principals identify effective teachers? Evidence on subjective performance evaluation in education. Journal of Labor Economics, 20(1), 101-136.

Klassen, R. M., \& Chiu, M. M. (2010). Effects on teachers' self-efficacy and job satisfaction: Teacher gender, years of experience, and job stress. Journal of Educational Psychology, 102(3), 741-756.

Kurt, T.; Duyar, I. \& Çalik, T. (2012) "Are we legitimate yet?: A closer look at the casual relationship mechanisms among principal leadership, teacher self-efficacy and 

collective efficacy", Journal of Management Development, Vol. 31 (1) , pp.71-86.

Levine, A. (2005). Educating School Leaders. New York, NY: The Education School Project. Washington, D.C.

McCormick, M. J. (2001). Self-efficacy and leadership effectiveness: Applying social cognitive theory to leadership. Journal of Leadership Studies, 8(1), 22-33.

Mojavezi, A. \&Tamiz, M. P. (2012). The impact of teachers' efficacy on students motivation and achievement. Theory and Practice in Language Studies, Vol. 2, No. 3, pp. 483491.

Page, C. S.; Pendergraft, B. \& Wilson, J.(2014)Examining Elementary Teachers' sense of efficacy in three settings in south east. Journal of inquiry and action in education, 5 (3)

Paglis, L. \& Green, S.G. (2002). Leadership self-efficacy and managers' motivation For leading change. Journal of Organizational Behavior, 23, 215-235.

Report published by Wallace Foundation, (2008). Becoming a leader: Preparing principals for today's schools

Schyns.B. (2004).The Influence of Self-Efficacy on Relationship of Leadership Behavior and Preparedness for Occupational Change.

Stevenson, H. (2015), The role of self-efficacy, confidence and resilience plays in leadership, Cleveland Consulting Group, INC.

Swan, B. G., Wolf, K.J., Cano, J (2011). Changes in teachers' self- efficacy from the student teaching experience through the third year of teaching. Journal of Agricultural Education Volume 52, Number 2, pp. 128-139

Scholz, U.; Dona, B. G.; Sud, S.; Schwarzer, R.(2002). Is General Self Efficacy a Universal Construct? European Journal of Psychological Assessment Psyc.ARTICLE; 18, 3; pg. 242

Shanmugam, M., Amaratunga, R.D.G., Haigh, R.P.(2019) Leadership styles: Gender similarities, differences and perceptions. Available from: https://www.irbnet.de/daten/iconda/CIB16523.pdf

Siwatu, K. O., \& Chesnut, S. R. (2015). The career development of preservice and in-service teachers: Why teachers' self-efficacy beliefs matter. In H. Fives M. Gregoire Gill (Eds.), International handbook of research on teachers' beliefs (pp. 212-229). NewYork: Routledge.

Tschannen-Moran, M. \& Gareis, C. (2005). Principals' sense of self-efficacy: Assessing a Promising construct Journal of Educational Administration, 42, 573-585.

Tschannen - Moran, M., \& Woolfolk Hoy, A. (2001). Teacher efficacy: Capturing and elusive construct. Teaching and Teacher Education, 17, 783-805.

Turnnidge, J. \& Côté, J. ( 2018). Applying transformational leadership theory to coaching research in youth sport: A systematic literature review. International Journal of Sport and Exercise Psychology 16(3), 327-342

Vaudroz, C., Berger, J. L. \& Girardet, C. ( 2015). The Role of Teaching Experience and Prior Education in Teachers' Self-Efficacy and General Pedagogical Knowledge at the Onset of Teacher Education: International Journal of Learning, Teaching and Educational Research 13(2), pp. 168-178

Weber, E.U., Blais, A. and Betz, E.N. (2002). A Domain Specific Risk-Attitude Scale: Measuring Risk Perceptions and Risk Behaviors. Journal of Behavioral Decision 
PJER, Vol 4, Issue 4 (2021)

A causal comparative...

Making, 15, 263-269. https://doi.org/10.1002/bdm.414.

Yukl, G. (2006). Leadership in Organizations (6th ed.). Upper Saddle River, NJ Pearson Education 